\title{
PENGUATAN EKONOMI KELAUTAN BERKELANJUTAN MELALUI PENDAMPINGAN SOCIO-ECOLOGICAL MARKET ECONOMY KEPADA MASYARAKAT PESISIR DI KABUPATEN BINTAN
}

\section{Strengthening of Sustainable Marine Economy Through Socio-Ecological Market Economy Assistance to Coastal Communities in Bintan Regency}

\author{
Dhani Akbar ${ }^{*}$, Ryan Anggria Pratama² \\ ${ }^{1)}$ Program Studi Hubungan Internasional, Fakultas Ilmu Sosial dan Ilmu Politik, Universitas \\ Maritim Raja Ali Haji, Tanjungpinang \\ ${ }^{2)}$ Program Studi Ilmu Pemerintahan, Fakultas Ilmu Sosial dan Ilmu Politik, Universitas \\ Maritim Raja Ali Haji, Tanjungpinang \\ *Korespondensi : akbardhani@umrah.ac.id
}

\begin{abstract}
ABSTRAK
Ekonomi pasar sosial bertujuan untuk menggabungkan kebebasan dalam pasar dengan kesejahteraan sosial berdasarkan ekonomi yang kompetitif. Ekonomi pasar sosial bertentangan dengan kebijakan laissez-faire dan sistem ekonomi sosialis dan menggabungkan kebebasan perusahaan swasta untuk beroperasi dengan regulasi dan intervensi negara untuk menjamin persaingan yang sehat, menjaga keseimbangan antara pertumbuhan ekonomi yang tinggi, rendahnya inflasi, rendahnya tingkat pengangguran, kondisi kerja yang baik, kesejahteraan sosial, dan pelayanan publik. Kegiatan ini sangat perlu untuk direalisasikan mengingat perlunya edukasi dan pendampingan masyarakat pesisir dalam mencari alternative livelihood-nya. Namun juga berbasis kepada pengembangan sistem ekonomi yang berbasis kepada Aspek Pasar Sosial dan Ekologikal. Adapun kegiatan belum dilaksanakan, maka diperlukan realisasi bersama dengan instansi terkait yang mampu menggandeng dan membuat pelaksanaan kegiatan ini tepat sasaran.
\end{abstract}

Kata kunci : Ekonomi Maritim, Penguatan, Sosialisasi

\begin{abstract}
A social market economy aims to combine a freedom in markets with social welfare based on a competitive economy. A social market economy contradicts to laissez-faire policies and socialist economic systems, combines the freedom of private enterprises to operate with state regulation and intervention to ensure fair competition, maintaining a balance between high economic growth, low inflation, low unemployment, good working conditions, social welfare, and public services. This activity really needs to be realized considering the need for education and assistance for coastal communities in finding alternative livelihoods. However, it is also based on the development of an economic system based on aspects of the social and ecological markets. As for the activities that have not been implemented, joint cooperation realization is needed with a relevant agencies that are able to cooperate and make the implementation of these activities on goals target.
\end{abstract}

Keyword : Maritime Economy, Strengthening, Socialization 


\section{PENDAHULUAN}

Sebagian besar wilayah Indonesia adalah terdiri dari lautan dan memiliki potensi kelautan cukup besar, dengan potensi yang dimiliki tersebut seharusnya dapat mensejahterakan kehidupan masyarakat nelayan yang menggantungkan hidup pada potensi kelautan (maritim) tersebut. Namun kenyataannya, kehidupan masyarakat nelayan senantiasa dilanda kemiskinan, bahkan kehidupan nelayan sering diidentikkan dengan kemiskinan. Tingkat kesejahteraan para pelaku perikanan (nelayan) pada saat ini masih di bawah sektor-sektor lain, termasuk sektor pertanian agraris. Nelayan (khususnya nelayan buruh dan nelayan tradisional) merupakan kelompok masyarakat yang dapat digolongkan sebagai lapisan sosial yang paling miskin diantara kelompok masyarakat lain di sektor pertanian

Masyarakat pesisir adalah masyarakat yang tinggal dan melakukan aktifitas sosial ekonomi yang berkaitan dengan sumber daya wilayah pesisir dan lautan. Dengan demikian, secara sempit masyarakat pesisir memiliki ketergantungan yang cukup tinggi dengan potensi dan kondisi sumber daya pesisir dan lautan. Masyarakat pesisir adalah sekumpulan masyarakat (nelayan, pembudidaya ikan, pedagang ikan, dan lanlain) yang hidup bersama-sama mendiami wilayah pesisir membentuk dan memiliki kebudayaan yang khas yang terkait dengan ketergantungannya pada pemanfaatan sumber daya pesisir. Masyarakat pesisir termasuk masyarakat yang masih terbelakang dan berada dalam posisi marginal. Selain itu banyak dimensi kehidupan yang tidak diketahui oleh orang luar tentang karakteristik masyarakat pesisir. Mereka mempunyai cara berbeda dalam aspek pengetahuan, kepercayaan, peranan sosial, dan struktur sosialnya. Sementara itu dibalik kemarginalannya masyarakat pesisir tidak mempunyai banyak cara dalam mengatasi masalah yang hadir.
Ciri khas wilayah pesisir jika ditinjau dari aspek biofisik wilayah, ruang pesisir dan laut serta sumber daya yang terkandung di dalamnya bersifat khas sehingga adanya intervensi manusia pada wilayah tersebutdapat mengakibatkan perubahan yang signifikan, seperti bentang alam yang sulit diubah, proses pertemuan air tawar dan air laut yang menghasilkan ekosistem yang khas. Ditinjau dari aspek kepemilikan, wilayah pesisir dan laut serta sumberdaya yang terkandung di dalamnya sering memiliki sifat terbuka. Karakteristik sosial ekonomi masyarakat pesisir yaitu bahwa sebagian besar pada umumnya masyarakat pesisir bermata pencaharian di sektor kelautan seperti nelayan, pembudidaya ikan, penambangan pasir dan transportasi laut. Dari segi tingkat pendidikan masyarakat pesisir sebagian besar masih rendah. Serta kondisi lingkungan pemukiman masyarakat pesisir, khususnya nelayan masih belum tertata dengan baik dan terkesan kumuh. Dengan kondisi sosial ekonomi masyarakatyang relative berada dalam tingkat kesejahteraan rendah, maka dalam jangka panjang tekanan terhadap sumberdaya pesisir akan semakin besar guna pemenuhan kebutuhan masyarakat pesisir.

\section{METODE}

Metode pelaksanaan dalam pelaksanaan Pengabdian Kepada Masyarakat ini adalah dengan membuat sebuah pelatihan dan pendampingan bersama instansi dan lembaga terkait dengan permasalahan peningkatan ekonomi masyarakat. Kegiatan dilakukan dalam bentuk ilmiah dan didampingi praktisi yang ahli di bidangnya, dengan beberapa sajian telaah kajian ilmiah dari ilmu Hubungan Internasional, tentang pentingnya menjaga kelestarian lingkungan laut untuk keberlangsungan hidup di masa yang akan datang.

Tempat pelaksanaan kegiatan pengabdian kepada masyarakat ini direncanakan berlokasi di wilayah pesisir yang secara geografis terletak di wilayah pesisir di 
Kabupaten Bintan, di mana desa tersebut direncanakan adalah Pengudang di Kabupaten Bintan. Dalam pelaksanaannya, akan melibatkan Dinas terkait, Kelompok Usaha Bersama, dan beberapa masyarakat dan pihak terkait.

\section{Teknik Pelaksanaan Kegiatan}

Proses pemberdayaan secara umum meliputi kegiatan-kegiatan sebagai berikut: merumuskan relasi kemitraan, mengartikulasikan tantangan dan mengidentifikasi berbagai kekuatan yang ada, mendefinisikan arah yang ditetapkan, mengeksplorasi sistem-sistem sumber, menganalisis kapabilitas sumber, menyususn frame pemecahan masalah, mengoptimalkan pemanfaatan sumber dan memperluas kesempatan-kesempatan, mengakui temuantemuan, dan mengintegrasikan kemajuankemajuan yang telah dicapai (Mulekom 1999).

Berkaitan dengan pemberdayan masyarakat pesisir, ada beberapa strategi yang dapat dilakukan untuk memberdayakan masyarakat pesisir, di antaranya adalah:

1. Strategi Fasilitasi, yaitu mengharapkan kelompok yang menjadi sasaran program sadar terhadap pilihan-pilihan dan sumberdaya yang dimiliki. Strategi ini dikenal sebagai strategi kooperatif, yaitu agen peubah secara bersama-sama dengan kliennya (masyarakat) mencari penyelesaian.

2. Strategi edukatif, yaitu strategi yang diperuntukan bagi masyarakat yang tidak mempunyai pengetahuan dan keahlian terhadap segmen yang akan diberdayakan.

3. Strategi persuasive, yaitu strategi yang ditujukan untuk membawa perubahan melalui kebiasaan dalam berperilaku. Strategi ini lebih cocok digunakan bila target tidak sadar terhadap kebutuhan perubahan atau mempunyai komitmen yang rendah terhadap perubahan.

4. Strategi kekuasaan, yaitu strategi yang efektif membutuhkan agen peubah yang mempunyai sumber-sumber untuk memberi bonus atau sanksi pada target serta mempunyai kemampuan untuk Usaha Bersama, dan beberapa masyarakat dan pihak terkait.

Untuk terlaksananya strategi-strategi tersebut, program unggulan harus dibuat dan dilaksanakan secara terstrukur dan terencana dengan komitmen yang kuat (Sen dan Nielsen 1996).

Berkaitan dengan strategi pemberdayaan dikatakan bahwa pengelolaan sumberdaya berbasis masyarakat (Community Based Management $=\mathrm{CBM}$ ) adalah suatu strategi untuk mencapai pembangunan berpusat pada masyarakat, dimana pusat pengambilan keputusan mengenai pemanfaatan sumberdaya secara berkelanjutan di suatu daerah berada di tangan organisasi-organisasi dalam masyarakat di daerah (Sen S, Nielsen, 1996).

Pengelolaan dengan konsep CBM ini hampir tidak ada campur tangan pemerintah. Pengelolaan dengan CBM ini memiliki resiko jika sumberdaya manusianya tidak siap. Namun demikian, dalam konsep pengelolaan sumberdaya alam berbasis masyarakat dalam kenyataannya juga tidak sepenuhnya berhasil tanpa keterlibatan pemerintah dalam implementasinya (Ferrer 1994). Masyarakat memiliki banyak kekurangan terutama dalam kualifikasi pendidikan, kesadaran akan pentingnya lingkungan, keuangan/ permodalan dan sebagainya.

Merumuskan model pemberdayaan ekonomi nelayan tradisional harus memperhatikan karakteristik mereka (Frith 1967 dalam Mubyarto 1994), secara geografis mereka sebagai sebuah masya-rakat yang memiliki kebudayaan tertentu yang menjadi pembeda dengan kelompok sosial lainnya (Kusnadi, 2009), dan mereka adalah pekerja keras, cerdik, dan ulet sehingga dapat bertahan hidup dan melepaskan diri dari belenggu rantai kemiskinan yaitu kemiskinan itu sendiri (Chambers, 1983). Di antara ketiga ke-lompok (buruh tani, petani gurem, dan nelayan) di pedesaan yang paling miskin, nelayanlah yang paling berat kehidup-annya, 
karena mereka itu sebagian merupakan kelompok yang terusir dari daerah-daerah pertanian (Mubyarto \& Kartodirdjo (1988). Menurut Suyanto (1996), ada dua faktor yang menyebabkan munculnya kerentanan yang semakin parah di antara keluarga nelayan yaitu: (1) irama musim dimana kehidupan nelayan yang sangat dipengaruhi oleh perubahan cuaca dan alam; dan (2) faktor harga dan daya tahan ikan hasil tangkapan nelayan dimana harga ikan sangat ditentukan oleh kondisi fisik ikan tersebut. Faktor-faktor tersebut di atas menyebabkan tingkatan pendapatan nelayan tradisional relatif rendah.

\section{Target dan Luaran}

Menurut Bornstein (2004) "Pengusaha sosial adalah orangorang dengan ide-ide baru untuk mengatasi masalah utama yang tak kenal lelah dalam mengejar visi mereka, yang tidak akan menyerah sampai mereka telah menyebar ide-ide mereka sejauh mereka bisa." (Saragih, 2017) Menurut Mulyadi (2005) ada empat masalah pokok yang menjadi penyebab dari kemiskinan, yaitu kurangnya kesempatan (lack of opportunity), rendahnya kemampuan (low of capabilities), kurangnya jaminan (low level-security), dan keterbatasan hak-hak sosial, ekonomi, dan politik sehingga menyebabkan kerentanan (vulnerability), keterpurukan voicelessness), dan ketidakberdayaan (powerlessness) dalam segala bidang. Secara normatif, diharapkan target daripada kegiatan ini adalah menghasilkan pemahaman kepada masyarakat bagaimana strategi pemasaran produk kerajinan. Diharapkan juga bahwa masyarakat mampu mengembangkan inovasi melalui upgrading barang melalui valueadded yang berkelanjutan. Selain itu, diharapkan juga, dengan mengundang beberapa instansi terkait dan juga pelaku bisnis, mampu didorong melalui kebijakankebijakan pemerintah yang mendukung dan mampu menjembatani kebutuhan masyarakat di wilayah tersebut.

\section{HASIL DAN PEMBAHASAN}

\section{Pelaksanaan Kegiatan Sosialisasi}

Pada dasarnya, pemberdayaan diletakkan pada kekuatan tingkat individu dan sosial. Pemberdayaan mengesankan arti adanya sikap mental yang tangguh dan kuat (Hikmat, 2001). Dari konsep pemberdayaan tersebut, dapat dikatakan bahwa pemberdayaan masyarakat pesisir dan lautan merupakan pemberdayaan masyarakat pesisir untuk memanfaatkan dan mengelola sumberdaya perikanan dan kelautan secara optimal dan lestari sebagai upaya meningkatkan kesejahteraan mereka. Dalam UU NO.20/2003 tentang system pendidikan nasional, tercantum pengertian pendidikan. Pendidikan adalah usaha sadar dan terencana untuk mewujudkan suasana belajar dan proses pembelajaran agar peserta didik secara aktif mengembangkan potensi dirinya sehingga memiliki kekuatan spiritual keagamaan, pengendalian diri, kepribadian, kecerdasan, akhlah mulia, serta ketrampilan yang diperlukan oleh dirinya, masyarakat,bangsa dan negara. Serta dalam Undang-Undang Dasar 1945 pada pasal 27 ayat 2 juga menyebutkan bahwa:"Tiap-tiap warga negara berhak atas pekerjaan dan penghidupan yang layak bagi kemanusiaan".

Berdasarkan uraian tersebut dapat dilihat bahwa negara sangat melindungi hak warga negaranya akan pendidikan tidak terkecuali bagi masyarakat nelayan karena pendidikan adalah faktor penting kemajuan suatu bangsa. Salah satu isu besar dalam manajemen sumberdaya dan lingkungan adalah pemerataan kesejahteraan dalam suatu generasi / intra generational equity dan antar generasi / inter generational equity (Messie, 2004). Intra generational equity merupakan pemerataan kesejahteraan untuk setiap kelompok atau komunitas masyarakat dengan adanya pemanfaatan suatu sumberdaya. Setiap pemanfaatan sumberdaya, ada pihak yang mendapatkan keuntungan dan mengalami peningkatan kesejahteraan serta ada pula pihak yang mendapat dampak negatif dan berkurang kesejahteraannya. 
Untuk itu perlu ada pemerataan kesejahteraan bagi kelompok masyarakat yang mendapat dampak negatif. Inter generational equity merupakan pemerataan kesejahteraan dimana kesejahteraan yang dimiliki oleh generasi sekarang tidak mengurangi kesejahteraan generasi yang akan datang. Memang masih menjadi perdebatan tanpa solusi tentang hak generasi saat ini menentukan kesejahteraan generasi yang akan datang. Tetapi untuk keperluan penelaahan terhadap program PEMP, maka diasumsikan harus ada pemerataan kesejahteraan antar generasi.

Model tersebut sesuai dengan pola yang dapat diaplikasikan di wilayah pesisir di kabupaten Bintan, terkhusus wilayah pulau terluar di perbatasan. Dari hasil observasi awal yang tim jumpai di Kabupaten Bintan, yang letaknya cukup jauh dari keramaian, pekerjaan yang paling dominan adalah pekerjaan sebagai nelayan dengan rata-rata penduduknya memiliki tingkat pendidikan sekolah dasar. Berdasarkan kedua alasan tersebut Tim melaksanakan pengabdian masyarakat yaitu berupa sosialisasi.

\section{KESIMPULAN}

Ada pun rencana tahapan berikutnya dari pengabdian ini adalah persiapan turun ke lapangan, jika memungkinkan akan melaksanakan pelatihan secara langsung, namun jika tidak, akan dialihkan kepada pelatihan online. Serta untuk kegiatan pengabdian masyarakat di Kabupaten Bintan tim dapat melaksanakan pendampingan berkaitan SEME dengan kelompok masyarakat yang dibutuhkan masyarakat sesuai dengan hasil diskusi dengan masyarakat pada saat pengabdian ini berlangsung.
Model tersebut sesuai dengan pola yang dapat diaplikasikan di wilayah pesisir di kabupaten Bintan, terkhusus wilayah pulau terluar di perbatasan.

\section{DAFTAR PUSTAKA}

Dale E. 1946. Audiovisual Methods in Teaching. United States America: Dryden Press.

Dewey J. 2007. The School and Society.

Jacoby B. 1996. Service-Learning in Higher Education: Concepts and Practices. San Francisco: Jossey-Bass Inc.

Jeffs T, \& Smith M. 2005. Informal Education : Conversation, Democracy, and Learning. Educational Heretics Press.

Maurer T. 2006. Cheerleading Skills. United States America: Rourke Pub.

Minter D, \& Reid M. 2007. Lightning in a Bottle: The Proven System to Create New Ideas and Products. Chicago: Sourcebooks. Monks FJ. 1982. Psikologi Perkembangan: Pengantar dalam berbagai bagiannya. Yogyakarta: Gadjah Mada Press.

Samnuzulsari T, \& Arieta S. 2017. Ipteks Bagi Masyarakat: Penguatan Pendidikan di Sekolah. (W. E. Yudiatmaja, Ed.). Tanjungpinang: Umrahpress.

Surakhmad W. 2009. Filosofi Pendidikan: Menemukan Kembali Landasan yang Hilang. In Pendidikan Nasional, Strategi, dan Tragedi (pp. 29-89). Jakarta: Buku Kompas.

Syah M. 1999. Psikologi Pendidikan dengan Pendekatan Baru. Bandung: Remaja Rosdakarya.

Yusuf M. 1978. Pokok-Pokok Pendidikan dan Pengajaran. Jakarta: Hidakarya Agung. 